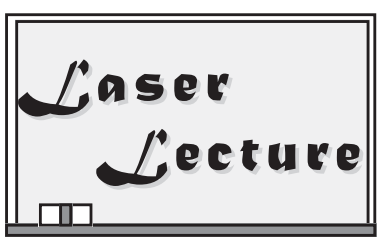

\title{
ロックイン増幅器と信号増幅器
}

\author{
安藤 正典 \\ (株)エヌエフ回路設計ブロック（テ223-8508 神奈川県横浜市港北区綱島東6-3-20）
}

\section{Lock-in Amplifier and Signal Amplifier}

\author{
Masanori ANDO \\ NF Corporation, 6-3-20 Tsunashima Higashi, Kohoku-ku, Yokohama, Kanagawa 223-8508
}

(Received February 16, 2012)

\begin{abstract}
Lock-in amplifier is a useful instrument for recovering small signals buried in noise. This paper describes the principle and an application example of the lock-in amplifier. In addition, it offers some advice on the selection and usage of signal amplifier.
\end{abstract}

Key Words: Lock-in amplifier, Phase Sensitive Detector, Current amplifier, Charge amplifier

\section{1. はじめに}

ここでは，センサの微弱な信号を検出するロックイン 増幅器と, 信号増幅器 (特に電流増幅器)について, その 原理，使用上の注意点，応用例を紹介する。

\section{2. ロックイン増幅器}

\section{1 ロックイン増幅器の概要}

微小な信号を測定しょうとすると, 不要な雑音と有用 な信号を分離する必要に迫られる。ロックイン増幅器 は，信号と雑音を周波数の違いに基づいて分離する。こ の点で帯域通過フィルタと似ているが, 入力信号の波形 ではなく，信号の大きさに比例した直流電圧が出力され る。測定対象は正弦波であり，その他の波形を入力する と，その基本波の実効值が測定される。直流は測定でき ないが，変調して交流化すれば測定できる。

ロックイン増幅器には, 周波数と位相の基準となる参 照信号を必要とする煩わしさがあるが，参照信号を用い ることで，信号の周波数に自動的に追従し，また位相を 測定できる利点が生じる。

\section{2 ロックイン増幅器の歴史}

ロックイン増幅器が最初に市販されたのは1962年, Princeton Applied Researchからのようである.1967年に は，エヌエフ回路設計ブロックが国産品の市販を始めて いる。 ロックイン増幅器は, 安価で高感度, 物理実験に 適した操作性が特徵であるが, 位相調整が面倒な 1 位相 型から，2位相型(直交検波)による位相調整の不要化, ヘテロダイン方式によるフィルタ調整の不要化と高感度
化, ディジタル化による操作性や機能・性能の向上を果 たし，現在では $1 \mu \mathrm{Hz}$ から数100 MHzまでをカバーする 製品群が存在する。

\section{3 ロックイン増幅器の動作原理}

ロックイン増幅器では，Fig. 1に示すように，被測定 信号と同じ周波数 $F$ と位相をもつ参照信号を入力信号に 乗じることで，直流と $2 F に$ 周波数変換したのち，高域 遮断周波数が $f_{c}$ である低域通過フィルタで雑音と $2 F$ を除 去し，直流だけを増幅する，雑音を除去してから増幅す るので，回路が飽和することなく，大きな雑音下で小さ な信号を測定できる。

\section{4 ダイナミックリザーブ}

信号フルスケールよりどれだけ大きな雑音を許容でき るかを示す数值をダイナミックリザーブと呼び，ロック イン増幅器では, フルスケール(レンジ) とは別に指定で きる。

前段の交流利得を下げ，後段の直流利得を上げれば， ダイナミックリザーブを大きくできるが，直流ドリフト を考慮すると，実用的な直流利得には上限がある。多段 交流増幅器の中間にフィルタを置き，フィルタの後ろで 交流利得を上げることでもダイナミックリザーブを大き くできるが，フイルタによる利得と位相のずれ，ドリフ トが加わる。

乗算から直流増幅までをディジタル演算で行う方式で は，直流ドリフトがないので，上記の問題は生じない．

2.5 等価杂隹音帯域幅と時定数

帯域通過フィルタに比べて, ロックイン増幅器は, 信 


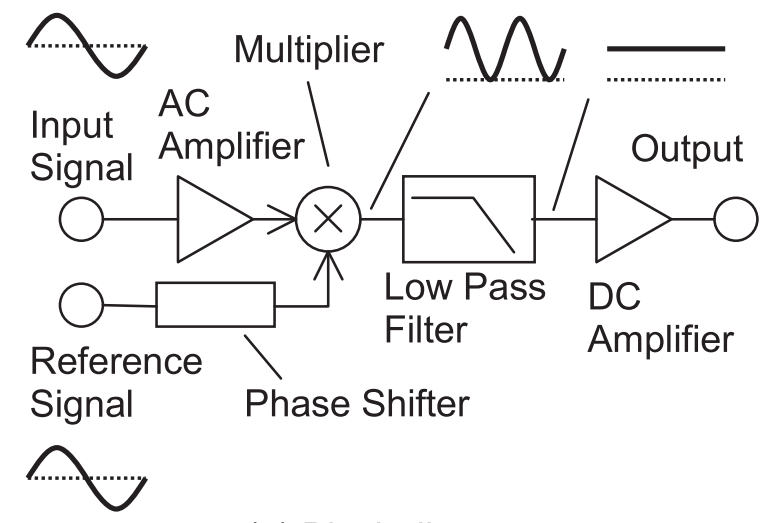

(a) Block diagram

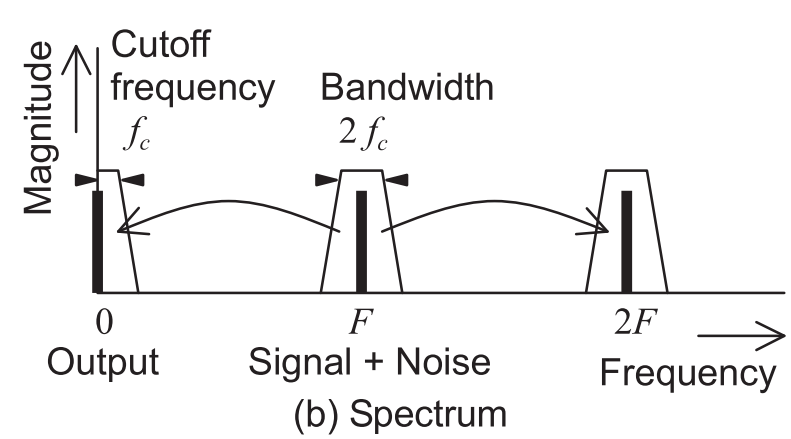

Fig. 1 Principle of lock-in amplifier.

号周波数への追従と狭帯域化がはるかに容易である。遮 断周波数が $f_{c}$ であ1次の低域通過フィルタを用いた ロックイン増幅器の等価雑音帯域幅 $B_{n}$ は次式になる.

$$
B_{n}=\pi f_{c}
$$

出力のランダム雑音は, 等価雑音帯域幅の平方根に比 例するので， $f_{c}$ を低くするほど雑音は除去される。ただ し, 応答速度とのトレードオフである。1次フィルタで は，その時定数を $T$ とすると，次の関係がある.

$$
B_{n}=1 /(2 T)
$$

遮断特性が緩やかなアナログフィルタでは， $2 F$ を除 去するために大きな時定数が要る. このため, 雑音が少 なくても, 周波数が低いと時定数を小さくできず, 測定 に時間がかかる. 高速応答を求めるときは, 高い周波数 を用いる。

ディジタル方式では，2Fにノッチを持つ移動平均 フィルタにより，信号のほぼ1周期で出力を整定させる ことができる。これにより低い周波数における応答時間 を短縮できる。

\section{6 位相の変化を検出する}

Fig. 1の乗算器は, 位相検波器またはPSD (Phase Sensitive Detector) と呼ばれ，Fig. 2に示すように出力 $X$ は参照 信号と被測定信号の位相差 $\theta$ の関数である. 参照信号系 に設けた移相器により位相差を約 $90^{\circ} に$ 調整すると，位 相に対する感度が高いうえ出力が小さいので, さらに増 幅できる，信号振幅が一定なら，微小な位相の変化を捉

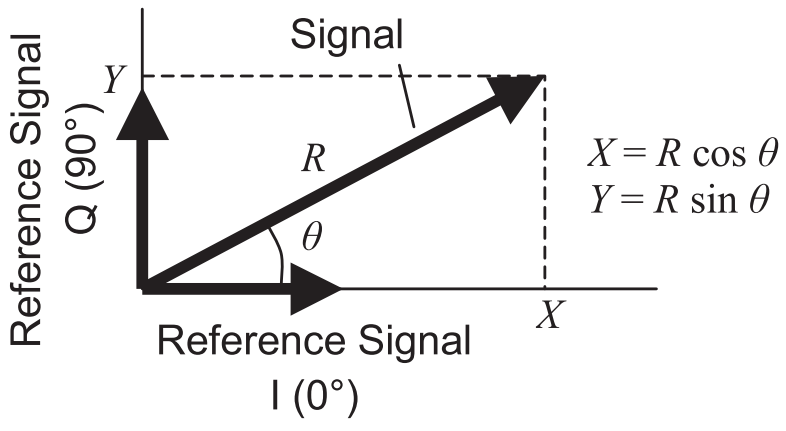

Fig. 2 Signal vector.

えられる。

\section{7 信号の大きさを測る}

位相検波器を一つしか持たない一位相ロックイン増幅 器では, 出力が最大になるように参照信号の位相を調整 した状態で，信号の大きさRを測定する。

二つの位相検波器を持つ二位相ロックイン増幅器で は, 二つの検波出力 $X$ と $Y$ か信号の大きさ $R$ と位相 $\theta$ を 計算で求めることができる。これは便利であるが，ラン ダム雑音の抑圧比が3dB劣る。言い換えると, 同じ $\mathrm{S} / \mathrm{N}$ (信号対雑音比)を得るのに2倍の応答時間が必要にな る.

なお，簡易なロックイン増幅器は，アナログスイッチ を用いて方形波参照信号を乗算するため，信号の奇数次 高調波に相当する周波数にも感度がある。その周波数に 雑音があると，妨害を受けてしまう。正弦波参照信号の 乗算を用いるディジタル方式では，この問題は生じな い.

\section{8 応用例}

信号を大きくする工夫と， ロックイン増幅器を用いた 微小信号測定を組み合わせた，気体分子濃度の測定例を Fig. 3に示す.

光音響セル内の気体にチョッピングしたレーザー光を 照射すると, 気体分子固有の波長で光が吸収される。 セ ルの音響的な共振周波数に合わせてチョッピングを行 い, レーザー光の吸収による加熱膨張で発生する音波を マイクロフォンで拾って, ロックイン増幅器で検出す

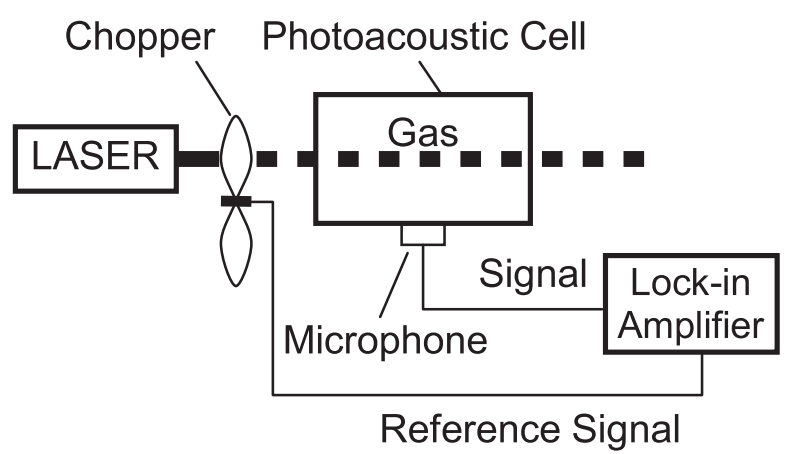

Fig. 3 Laser photoacoustic spectroscopy. 
る. 強いレーザー, セルの共振, ロックイン増幅器の組 み合わせで，低濃度の測定を実現している。

\section{3. 信号增幅器}

\section{1 増幅器の選択}

信号源インピーダンスが低いときは電圧増幅器を用い ればよい. 信号源インピーダンスが高いセンサに対して は, 一般に電流増幅器を用いる。信号源インピーダンス が高い場合, 電圧増幅器を用いると, その入力インピー ダンスで信号が減衰したり, 接続ケーブルなどの静電容 量を充放電するために応答が遅くなる，圧電素子を用い た加速度センサなど, 電荷出力型のセンサから信号を受 けるときは, 電荷増幅器(チャージアンプ)を用いる.

\section{2 電圧増幅器}

一般的な低雑音増幅器が発生する入力換算電圧雑音密 度 $e_{n}$ は数 $\mathrm{nV} / \sqrt{\mathrm{Hz}}$ であるが, $1 \mathrm{nV} / \sqrt{\mathrm{Hz}}$ 以下の増幅器も入 手できる，信号源インピーダンスが低ければ, インピー ダンス変換トランスを用いることで, さらに低雑音を実 現できる。

増幅器自身が杂隹音を発生するため，増幅器を用いると 必ずS/Nは劣化する。この劣化の度合いを雑音指数 (NF: Noise Figure) と言う.

$$
\mathrm{NF}=20 \log _{10}\left(\frac{\text { 入力信号 } / \text { 入力雑音 }}{\text { 出力信号 } / \text { 出力雑音 }}\right) \quad[\mathrm{dB}]
$$

NFは信号源抵抗と周波数によって変化するので，実 際の信号源や測定周波数においてNFが小さい増幅器を 選択する。

\section{3 電流増幅器 (電流入力アンプ)}

電流増幅器は, 入力電流に比例した出力電圧を発生す る増幅器である。変換利得はトランスインピーダンスと 呼ばれV/A単位で示される。これはインピーダンスの単 位 $\Omega$ と同じ次元である.

Fig. 4に基本的な電流増幅器を示す. 演算増幅器によ り入力端子の電圧は $0 \mathrm{~V} に$ 保たれ, センサで発生した電 流 $I$ は帰還抵抗 $R_{f} に$ 流れて, 電圧 $V に$ 変換される.

$$
V=R_{f} \times I
$$

トランスインピーダンスは帰還抵抗に等しい。電流雑音 が小さい演算増幅器を選択するなど適切に設計すると, 入力換算電流雑音密度 $i_{n}$ は帰還抵抗 $R_{f}$ の熱雑音とほぼ等 しくなる

$$
i_{n}=\sqrt{4 k T / R_{f}} \quad[\mathrm{~A} / \sqrt{\mathrm{Hz}}]
$$
$k$ はボルツマン定数, Tは絶対温度

電流増幅器の高域遮断周波数 $f_{c}$ は帰還抵抗の浮遊容量 を $C_{f}$ として，およそ次式で与えられる。

$$
f_{c}=1 /\left(2 \pi R_{f} C_{f}\right)
$$
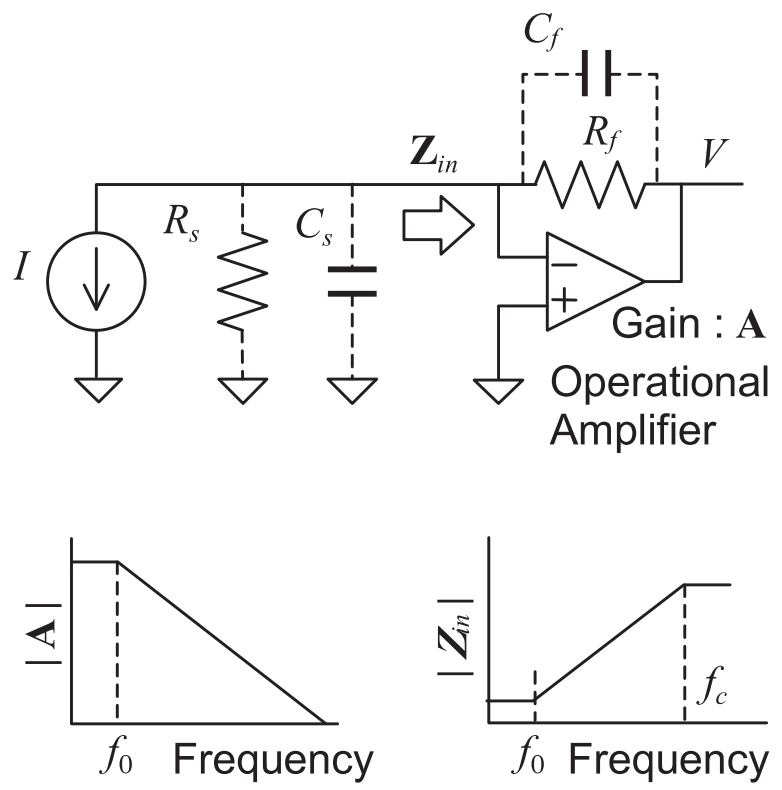

Fig. 4 Basic current amplifier.

て，室温における入力換算電流雑音密度 $130 \mathrm{fA} / \sqrt{\mathrm{Hz}}$, 高域遮断周波数 $100 \mathrm{kHz}$ 程度が得られる。

入力インピーダンス $Z_{i n}$ は理想的には $0 \Omega$ あ゙り，信号 源抵抗 $R_{s}$ や信号源と接続ケーブルの静電容量 $C_{s}$ の影響を 受けない，実際には，帰還抵抗の浮遊容量 $C_{f}$ と演算増幅 器利得の周波数特性によって誘導性になり，負性抵抗を 示すこともある。これにC ピークを生じたり，発振することがある。 $C_{s}$ が大きいと きは， $C_{f}$ を大きくしてピークや発振を抑えるが， $f_{c}$ が下 がってしまう。C $C_{s}$ はできるだけ小さく抑えることが望ま しい，センサに電流増幅器を内蔵できれば最良である。 センサ自身の静電容量が小さいのなら, 高感度と高速性 を両立しやすい. IBM社の初期のSTM (Scanning Tunneling Microscope) では, 利得 $1 \times 10^{10} \mathrm{~V} / \mathrm{A}$ で帯域幅 $1 \mathrm{MHz}$ 得たようである。

汎用電流増幅器の最近の開発事例では, 工夫を凝らす ことで $C_{s} 100 \mathrm{pF}$, 利得 $1 \times 10^{9} \mathrm{~V} / \mathrm{A}$ において, 入力換算電 流雑音密度 $5.8 \mathrm{fA} / \sqrt{\mathrm{Hz}}$, 高域遮断周波数 $100 \mathrm{kHz}$ が得ら れている.

電流増幅器が発振した場合, $C_{f}$ を調整できなくても, 入力に抵抗を直列に挿入して負性抵抗を打ち消すと発振 を止められる。 $R_{s}$ が小さいかまたは $C_{s}$ が大きいと，演算 増幅器の入力換算電圧雑音が増幅されて $\mathrm{S} / \mathrm{N}$ 劣化する ので, 電圧雑音も無視できない

\section{4 電荷増幅器}

Fig. 4で， $R_{f}$ を十分に大きくして， 正確な $C_{f}$ で入力電荷 を電圧に変換すれば電荷増幅器になる。リーク電流で出 力が発散するのを防ぐため, 通常は有限の $R_{f}$ を用いる. このため交流しか扱えない. 出力のドリフトを許容して $R_{f}$ を省くときは, 定期的に $C_{f}$ を放電して初期化する必要 がある。

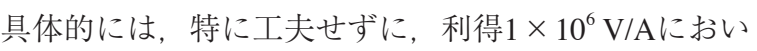


3.5 低雑音ケーブル

微小信号の伝送には信号線のシールドが重要である が, 一般的なシールド電線では摩擦電気による雑音が発 生する。このため, 感度の高い電流増幅器を用いるとき は, 絶縁体表面に半導電層を設けた低雑音ケーブルを用 いる。ささもないと，わずかな振動でも雑音が発生する。

電位差がある導体間の距離が変化すると, 同様に杂隹音 電流が発生する。直流電源ラインとむき出しの信号線が ごく近づいていれば，電源電圧に含まれる小さな雑音で さえ, 浮遊容量を介して妨害を与える。微小電流の取り 扱いには細心の注意が必要である。
4. まとめ

ロックイン増幅器は, 微小信号の測定に便利ではある が，初めて手にすると戸惑うことも多い。ここで紹介し た内容が, ロックイン増幅器やその周辺機器を理解し活 用する一助になれば幸いである。

\section{参考文献}

1）ロックインアンプ技術解説集（(株)エヌエフ回路設計ブ ロック，2000).

2) 下坂 玩哉, 「標準ガスの高感度測定法に関する調査研究」, （産総研計量標準報告 Vol.3, No.4, 2005）.

3）公開特許公報 H04-233475, インターナショナル・ビジネ ス・マシーンズ・コーポレイション. 